RÊGO, ER; FERREIRA, APS; PEREIRA, DM; PEREIRA, AM; PEREIRA, OL; FINGER, FL. 2019. Artificially cooling of onion bulbs stored in brickworkpatterned vertical silos. Horticultura Brasileira 37: 234-238. DOI - http://dx.doi.org/10.1590/S0102-053620190216

\title{
Artificially cooling of onion bulbs stored in brickwork-patterned vertical silos
}

\author{
Elizanilda R Rêgo ${ }^{1} \mathbb{D}$; Ana Paula S Ferreira ${ }^{2} \mathbb{D}$; Danilo Manoel Pereira ${ }^{3} \mathbb{D}$; Ariana M Pereira ${ }^{3} \mathbb{D}$; Olinto L \\ Pereira ${ }^{3} \mathbb{D}$; Fernando Luiz Finger ${ }^{3} \mathbb{D}$
}

${ }^{1}$ Universidade Federal da Paraíba (UFPB), Areia-PB, Brazil; elizanilda@pq.cnpq.br; ${ }^{2}$ Centro de Ensino Superior de Conselheiro Lafaiete (CES-CL), Conselheiro Lafaiete-MG, Brazil; ana.sato.ferreira@gmail.com; ${ }^{3}$ Universidade Federal de Viçosa (UFV), Viçosa-MG, Brazil ffinger@ufv.br

\begin{abstract}
Onion is the third most consumed vegetable worldwide, such as potatoes and tomatoes. Its conservation is influenced by temperature and humidity, and greatest losses occur at postharvest due to lack of storage infrastructure. Thus, the aim of this study was to evaluate the effect of partial cooling in vertical silo on postharvest conservation of cured onion bulbs cultivar Bola Precoce. The experimental design was completely randomized, with six replicates, arranged in split plot scheme. Plots consisted of two storage conditions: onion bulbs stored in silo 1 at room temperature (T1) and bulbs stored in silo 2 with artificial cooling (T2). Subplots were two periods of bulb removal from storage ( 0 and 14 days). We evaluated peel color, using chroma $\left(\mathrm{C}^{*}\right)$ and internal and external luminosity $\left(\mathrm{L}^{*}\right)$; relative water content (TRA) of peel and pulp of bulbs and fresh mass loss (PMF) when the experiment was installed and after 14 days for both experiments and at 21 days for $\mathrm{T} 2$. The average temperatures obtained in both silos were 30.4 and $16.4^{\circ} \mathrm{C}$, respectively. Bulbs of T1 had 14 days shelf life whereas, bulbs of T2 had a shelf life of 21 days. Bulbs of T1 showed lighter peel on day zero. The 14-day storage made the bulbs lighter in T2. In relation to pulp color, storage period made pulp lighter in both treatments. On day 14, bulbs of T1 showed lighter pulp color comparing to bulbs of T2. Both treatments showed similar behavior on day zero for internal chroma. After 14 days storage, internal and external chroma was higher in bulbs of T2. Storage period reduced internal hue only in bulbs of T2 which showed lower internal hue in both evaluation periods. TRA was higher in T1 in both evaluation periods. PMF was higher according to storage period; however loss did not differ between treatments. Storage of onion bulbs in cooled silos increased their viability in 7 days, in relation to storage without refrigeration.
\end{abstract}

Keywords: Allium cepa, postharvest storage, refrigeration.

\section{RESUMO}

Resfriamento artificial em bulbos de cebola armazenados em silos verticais de alvenaria

A cebola é a terceira hortaliça mais consumida no mundo, ao lado da batata e do tomate. Sua conservação é influenciada pela umidade e temperatura e, as maiores perdas pós-colheita ocorrem devido à falta de infraestrutura no armazenamento. $\mathrm{O}$ objetivo do presente trabalho foi avaliar o efeito do resfriamento parcial de silo vertical na conservação pós-colheita de bulbos curados de cebola, cultivar 'Bola Precoce'. O delineamento experimental utilizado foi inteiramente casualisado, com seis repetições, em esquema de parcelas subdivididas. As parcelas foram constituídas de duas condições de armazenamento [bulbos de cebola armazenados em silo 1 com temperatura ambiente (T1) e bulbos armazenados em silo 2 resfriado (T2)] e as subparcelas foram consideradas dois períodos de retirada dos bulbos do armazenamento (0 e 14 dias). Foram avaliados a cor da casca, a partir do croma $\left(\mathrm{C}^{*}\right)$ e luminosidade $\left(\mathrm{L}^{*}\right)$ interna e externa; teor relativo de água (TRA) da casca e da polpa dos bulbos e perda de massa fresca (PMF) no momento de instalação do experimento e após 14 dias para ambos os experimentos e aos 21 dias para o T2. As médias de temperaturas obtidas em ambos os silos foram 30,4 e $16,4^{\circ} \mathrm{C}$, respectivamente. A vida de prateleira dos bulbos do $\mathrm{T} 1$ foi 14 dias enquanto do T2 foi 21 dias. Os bulbos do T1 apresentam-se com casca mais clara no dia 0 . O tempo de 14 dias de armazenamento tornou os bulbos mais claros no T2. Em relação à cor da polpa, o tempo de armazenamento tornou a polpa mais clara em ambos tratamentos. No dia 14 os bulbos do T1 apresentaram polpa mais clara que os do T2. Os tratamentos apresentaram comportamento semelhante no dia zero para croma interno. Após quatorze dias de armazenamento, o croma interno e externo foi maior nos bulbos do T2. O tempo de armazenamento reduziu o Hue interno apenas no T2 que apresentou menor Hue interno que o $\mathrm{T} 1 \mathrm{em}$ ambos os períodos de avaliação. O TRA foi maior no T1 que no T2 em ambos os períodos de avaliação. A PMF foi maior com tempo de armazenamento, no entanto, não diferiu entre tratamentos. $\mathrm{O}$ armazenamento de bulbos de cebola em silo resfriado aumentou em 7 dias a viabilidade dos mesmos, em relação ao silo sem refrigeração.

Palavras-chave: Allium cepa, conservação pós-colheita, refrigeração.

Received on August 22, 2018; accepted on April 18, 2019 
$\mathrm{O}$ nions (Allium cepa) are grown due to its therapeutic value, its flavor and aroma which give them exceptional qualities such as condiments (Carvalho, 1980). Bulbs have great versatility of uses: fresh, cooked, chopped, dehydrated and in processed foods.

Post-harvest diseases, sprouting, rooting and mass loss through dehydration are primary causes of product deterioration (Matos, 1987). Onion storage involves both pre-harvest and post-harvest factors. Among these factors are storage potential of the cultivar, cultural practices used in postharvest, appropriate harvest and cure, as well as temperature and relative humidity for storage (Proctor et al., 1981; Pretopoulous et al., 2017). Sekara et al. (2017) highlight that besides the degree of bulb maturity at harvest and storage conditions, genetic factor is determinant in shelf life and is related to bulb size and dry mass content.

Sprouting is one of the first symptoms of post-harvest deterioration of onions (Vidigal et al., 2010), bulb dormancy period comes to an end and reflects presence of diseases, making this product inappropriate for consumption (Brewster, 1994).

High-quality onions have to present firm bulbs, dry peel adhering to bulb, without damages or diseases (Moretti, 2004). Inappropriate pre and post-harvest practices cause high losses, reaching $27 \%$, as reported by Moura Guerra et al. (2014) in Santarém-PA, and all the collected onions showed some kind of damage, being $55 \%$ microbiological damages, $28 \%$ mechanic damages and $17 \%$ physiological damages.

Some producers wait for a lower offer and better prices to commercialize onion bulbs (Vidigal et al., 2010). That is why knowing onion storage technology is essential, since it allows more efficient production storage, ensuring posterior gradual distribution, keeping constant product flow throughout the year (Matos, 1987). However, the difficulty in storing vegetables generates large price fluctuations. For onions, the seasonal instability of prices is due to the lack of infrastructure of warehouses throughout the country and the excessive intermediation of the product along the marketing chain (Zaidhaft, 1984).

In Brazil, three types of storage for onions can be verified: warehouses or storage under natural conditions; ventilated warehouses; and refrigerated warehouses. The most commonly used is storage in ordinary cameras, in conventional warehouses or in rustic systems of small properties. Among these cameras, the best results are obtained in refrigerated warehouses, however, this type of storage needs high investment and maintenance cost is high (Volkind et al., 1993).

A low-cost method to be used is the ventilation system, which can be used to cure and store bulbs, being the most economic way to control environmental conditions and post-harvest loss reduction (Jamieson, 1980). Thus, the aim of this study was to evaluate the effect of partial cooling in vertical silo for post-harvest conservation of cured onion bulbs cultivar 'Bola Precoce'.

\section{MATERIAL AND METHODS}

The onion bulbs (Allium cepa) cultivar Bola Precoce were from Guiricema-MG. The experiment was carried out from 2010 to February 2011, at Laboratório de Pós-colheita do Departamento de Fitotecnia and at Laboratório de Equipamentos e Ensaios do Departamento de Engenharia Agrícola, UFV.

The experimental design was completely randomized, with six replicates, arranged in split plot scheme; plots consisted of two storage conditions $(\mathrm{T} 1=$ silos at room temperature, $\mathrm{T} 2=$ silos with artificial cooling system) and at subplots, two periods of bulb removal from storage ( 0 and 14 days).

After natural cure in a shed (Cardoso et al., 2016), bulbs were selected, defective and rotten bulbs were removed.

In $\mathrm{T} 1$, the authors used $400 \mathrm{~g}$ of bulbs in a vertical cylinder silo, $1-\mathrm{m}$ diameter and $1.5-\mathrm{m}$ height, with perforated bottom plate, closed top (Ferreira et al., 2015). In T2, the authors used $400 \mathrm{~g}$ of bulbs stored in silos, with air cooler coupled to the silo floor. The air cooler was developed by the company COOLSSED and reduces the temperature by up to $10^{\circ} \mathrm{C}$ relative to room temperature. Air cooler was activated every two days in the morning during 3 hours until the internal temperature of the silo reached $15^{\circ} \mathrm{C}$. Bulb mass temperature was measured using an Air Master model thermometry system equipped with thermocouple sensors, being the readings performed daily, always at the same time. T1 kept average temperature at $30.4^{\circ}$ and $\mathrm{T} 2$ at $16.4^{\circ} \mathrm{C}$. Evaluated traits were: peel color, using chroma $\left(\mathrm{C}^{*}\right)$ and external and internal luminosity $\left(\mathrm{L}^{*}\right)$; water relative content (TRA) of peel and pulp of bulbs; fresh mass loss and shelf life. Data were collected when the experiment was installed, after 14 days for both treatments and at 21 days for $\mathrm{T} 2$.

The color of inner and outer parts of the bulbs, using six readings for each, was determined using the colorimeter Colortec-PCM (Minolta), where axis L (luminosity) shows maximum value 100 (white) and minimum 0 (black). Axes $a$ and $b$ do not show specific numbers: red is represented by $+a$, and green represented by $-a$, yellow by $+b$ and blue, $-b$. Hue angle or color angle was determined using the expression $\tan ^{-1}$ (b/a), being evaluated in degrees where $+\mathrm{a}(0)$ is red, $-\mathrm{b}(90)$ yellow, $-\mathrm{a}(180)$ green and -b (270) blue (MinoltaCorp., 1994).

To determine water relative content of bulbs (TRA), 11-mm diameter discs were taken from outer parts of onion bulbs, with the aid of a metal punch, determining fresh mass (MF). Afterwards, the discs were placed in 2-cm thick polyurethane foam saturated with water for $6 \mathrm{~h}$ (time required for maximum saturation), and weighed, obtaining turgid mass (MT). Right after, in order to determine dry mass (MS), the discs were placed in a hot air chamber at $70^{\circ} \mathrm{C}$ until constant mass. TRA was obtained using the equation of Weatherley (1950), TRA $=[(\mathrm{MF}-\mathrm{MS}) /$ (MT-MS)x100].

Fresh mass loss (PMF) was determined by the difference between initial mass and final mass at storage, expressed in percentage.

Obtained data were submitted to analysis of variance and when significant 
difference was detected, means were compared by Tukey test $(\mathrm{p} \leq 0.05)$. Statistics analyses were performed using Genes program (Cruz, 2013).

\section{RESULTS AND DISCUSSION}

Bulbs of treatment $\mathrm{T} 1$ (silos at room temperature), were discarded after 14 storage days due to high incidence of black mold (Aspergillus niger) $(90 \%)$ and sprouted bulbs (2\%). Bulbs of T2 (silos with artificial cooling system), were kept stored for 21 days. After this period, $85 \%$ of bulbs showed black mold and $1.0 \%$ showed bud-sprouting (non-shown data).

Significant interaction was noticed using $F$ test $(p \leq 0.05)$, for all evaluated variables (Tables 1 and 2 ).

Significant difference between treatments was verified on day zero, for external luminosity, external chroma and internal hue (Table 1). In treatment $\mathrm{T} 1$, no time effect on external luminosity was verified, whereas in $\mathrm{T} 2$ external luminosity increased in $187.18 \%$ in 14 days (Table 1). Only on day zero, significant difference between the treatments was noticed: higher external luminosity in T1 (Table 1), due to randomized obtainment of onion bulbs when the experiment was installed. Higher external luminosity forms lighter bulbs. Bulbs kept in cooled silos (T2) showed high increase, $344.8 \%$, in external luminosity at 21 days (data not shown); it means that, at the end of storage, bulbs were lighter compared to their color on the day of experiment installation. Onions 'Granex-33-Híbrid' stored at room temperature, showed a decrease in luminosity while in onions 'Baia Periforme' light browning was observed (Yokomizo et al., 1977). These data did not corroborate with the data shown in this study for internal and external luminosity.

Some difference for internal luminosity throughout storage was observed in each treatment, with an increase of 389.63 and $244.52 \%$ in T1 and T2, respectively (Table 1). On day zero, the treatments did not show any difference for luminosity; however, on day $14, \mathrm{~T} 1$ showed $10.91 \%$ higher luminosity than T2 (Table 1). The bulbs stored in cooled silos showed a small increase of values for internal luminosity throughout storage, up to 21 days, (data not shown), it means, that the bulbs showed lighter pulp when compared to bulbs stored in lower luminosity. This increase may have happened due to enzymatic actions occurring inside the bulb throughout storage, besides water loss caused by the passage of air under the bulbs. According to Berno (2013), the passage of air through bulbs causes greater loss of surface water and consequently changes in color.

Silos with artificial cooling system (T2) and at room temperature (T1) showed different behaviors, on day zero, for external chroma and the same for internal chroma (Table 1). After 14 days of storage, external chroma of bulbs was higher in $\mathrm{T} 2$ and internal chroma increased in both treatments (Table 1). Bulbs of T2 showed an increase in chromacity after 14 days of storage, being this increase for external and internal chroma of 5,5\% and $29 \%$, respectively, when compared to day zero and at 21 days (data not shown). Bulbs of $\mathrm{T} 1$ did not undergo changes in color of inner and outer parts.

Partially similar data were observed by Aca \& Durigan (2004). These authors observed that internal bulb color was not affected by cooling storage period, however, when these bulbs were taken to room temperature conditions, nonsignificant tendency to reduce color angle and chromaticity (more yellowish coloration) was noticed.

Treatment 1 showed higher internal hue values when compared to treatment 2 , both on day zero after closing silos 1 and beginning the use of silo 2 with artificial cooling system, as at 14 days after storage. Only T2 showed a reduction of internal hue at 14 days (Table 1). Thus, control bulbs, at 14 days, showed more yellowish coloration and the bulbs in cooled silos showed yellowish red color. After 21 days, internal hue (45.79, non-shown data) decreased, so the bulbs kept in cooled silos presented darker reddish-yellow color. Since these values are between 0 (red) and 90 (-b yellow), the onions presented better internal appearance,

Table 1. Unfolding of the interaction of storage and time for internal and external coloration indexes of onions 'Bola Precoce' during storage. Viçosa, UFV, 2014.

\begin{tabular}{|c|c|c|c|c|c|c|}
\hline \multirow{2}{*}{ Treatment } & \multicolumn{2}{|c|}{ External luminosity (L*) } & \multicolumn{2}{|c|}{ Internal luminosity $\left(\mathrm{L}^{*}\right)$} & \multicolumn{2}{|c|}{ External chroma ( $\left.C^{*}\right)$} \\
\hline & 0 days & 14 days & 0 days & 14 days & 0 days & 14 days \\
\hline $\mathrm{T} 1$ & $59.86 \mathrm{aA}$ & $61.88 \mathrm{aA}$ & $14.18 \mathrm{aB}$ & $69.43 \mathrm{aA}$ & $25.80 \mathrm{aA}$ & $23.40 \mathrm{aA}$ \\
\hline $\mathrm{T} 2$ & $22.62 \mathrm{bB}$ & $64.69 \mathrm{aA}$ & $18.17 \mathrm{aB}$ & $62.60 \mathrm{bA}$ & $25.40 \mathrm{bB}$ & $26.13 \mathrm{aA}$ \\
\hline CV (\%) plot & \multicolumn{2}{|c|}{4.24} & \multicolumn{2}{|c|}{9.42} & \multicolumn{2}{|c|}{16.28} \\
\hline CV (\%) subplot & \multicolumn{2}{|c|}{7.32} & \multicolumn{2}{|c|}{9.77} & \multicolumn{2}{|c|}{13.32} \\
\hline
\end{tabular}

\begin{tabular}{lccccc}
\hline & \multicolumn{2}{c}{ Internal chroma $\left(C^{*}\right)$} & & \multicolumn{2}{c}{ Internal hue $\left({ }^{\circ} \mathrm{h}\right)$} \\
\cline { 1 - 2 } \cline { 5 - 6 } T1 & $14.18 \mathrm{aB}$ & $15.47 \mathrm{aA}$ & & $101.50 \mathrm{aA}$ & $101.25 \mathrm{aA}$ \\
$\mathrm{T} 2$ & $24.35 \mathrm{aB}$ & $28.00 \mathrm{aA}$ & & $81.99 \mathrm{bA}$ & $61.63 \mathrm{bB}$ \\
\hline CV (\%) plot & \multicolumn{2}{c}{31.91} & \multicolumn{2}{c}{1.52} \\
\hline CV (\%) subplot & \multicolumn{2}{c}{36.31} & \multicolumn{2}{c}{2.14} \\
\hline
\end{tabular}

$\mathrm{T} 1=$ silo at room temperature; $\mathrm{T} 2=$ silo with artificial cooling; Means followed by same letters, uppercase (line) and lowercase (column), do not differ significantly by Tukey test, $5 \%$ probability. 
as verified in onions of $\mathrm{T} 1$ at 14 days. Miguel \& Durigan (2007) observed that bulb internal color was not affect by cooling storage period. Berno (2013) found oscillations of luminosity, chroma and hue angle values in relation to days and storage temperature in minimally processed purple onions, due to anthocyanin migration from the last layers to layers where this pigment was not verified throughout the storage. Both $\mathrm{T} 1$ and $\mathrm{T} 2$ bulbs showed a decrease in internal relative water content. The decrease observed in this study was 45.7 and $44.1 \%$ for $\mathrm{T} 1$ and $\mathrm{T} 2$ (Table 2). After 21 days of storage, T1 did not show excessive loss of relative water content $(9.89 \%)$ (Figure 1). Significant difference between T1 (103.04\%) and T2 $(19.89 \%)$ on day zero was verified, and after 14 days of storage, the values of $55.95 \%$ and $11.10 \%$ for $\mathrm{T} 1$ and $\mathrm{T} 2$, respectively, were obtained (Table 2 ); this occurred due to the passage of cooled air under the onion bulbs, removing moisture from the external leaves, resulting in drying these layers. According to Cardoso et al. (2016), ventilation and heat allow the external leaves of the bulbs to be dried offering more effective protection against water loss in inner layers.

Treatments $\mathrm{T} 1$ and $\mathrm{T} 2$ showed significant fresh weight loss over 14 days of storage $(0.14$ and $1.06 \%)$, as observed in Table 2. T2 showed greater weight loss than $\mathrm{T} 1$ after storage (Table 2), due to moisture removal from outer bulb catalogs, influenced by the genotype and plant maturation stage after harvest (Soares et al., 2004). Fresh weight loss was between 12.4 and $14.1 \%$ in onion bulbs cv. Texas Grano 502 PRR stored during 40 days under environmental conditions after curing under field conditions (Resende \& Costa, 2008). The longer the shelf life at room temperature, the greater fresh weight loss (Miguel \& Durigan, 2007). According to Garcia et al. (1977), weigh

Table 2. Unfolding of the interaction of storage and time in relation to relative water content (TRA), fresh weight loss of onion 'Bola Precoce' through-out storage time. Viçosa, UFV, 2014.

\begin{tabular}{llllll}
\hline \multirow{2}{*}{ Treatment } & \multicolumn{2}{c}{ Internal TRA (\%) } & & \multicolumn{2}{c}{ Fresh weight loss (\%) } \\
\cline { 2 - 3 } \cline { 5 - 6 } & 0 days & $\mathbf{1 4}$ days & & 0 days & 14 days \\
\hline T1 & $103.04 \mathrm{aA}$ & $55.95 \mathrm{aB}$ & & $0.00 \mathrm{aB}$ & $0.14 \mathrm{aA}$ \\
$\mathrm{T} 2$ & $19.89 \mathrm{bA}$ & $11.10 \mathrm{bB}$ & & $0.00 \mathrm{aB}$ & $1.06 \mathrm{aA}$ \\
\hline CV (\%) plot & \multicolumn{2}{c}{14.27} & & \multicolumn{2}{c}{51.86} \\
CV (\%) subplot & \multicolumn{2}{c}{19.63} & & \multicolumn{2}{c}{51.86} \\
\hline
\end{tabular}

$\mathrm{T} 1=$ silo at room temperature; $\mathrm{T} 2=$ silo with artificial cooling; Means followed by same letters, uppercase (line) and lowercase (column), do not differ significantly by Tukey test, $5 \%$ probability.

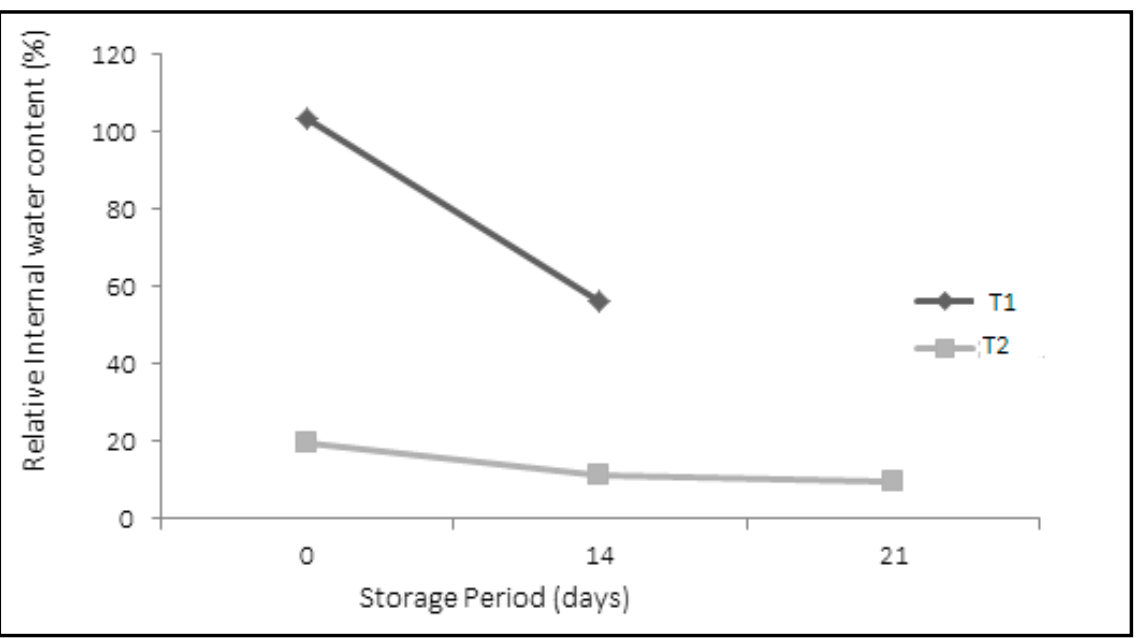

Figure 1. Average relative internal water content (\%) in onion bulbs stored in silo at room temperature (T1) and artificially cooled silo (T2). Viçosa, UFV, 2014. loss is responsible for $30 \%$ of fungi in onions, mainly Aspergillus niger, a microorganism predominantly found in the treatments of this study along storage. Distinct behavior of daily bulb fresh weight loss is dependent of the cultivar, water vapor transfer rate from the interior of the bulb to the environment, bulb neck closure, moisture of pseudostem or bulb size and shape (Soares et al., 2004). Weight loss is a limiting factor to store this product, because besides resulting in serious economic losses, it is indicative of aging.

Storage of onion bulbs in cooled silos increased its availability in 7 days, when compared to storage of bulbs in silos with an artificial cooling system.

\section{ACKNOWLEDGEMENTS}

To FAPEMIG and to CNPq for financial support.

\section{REFERENCES}

ACA, M; DURIGAN MFB; DURIGAN, JF; MORETTI, CL. 2004. Postharvest quality of twelve onion cultivars grown in the southeast of Brazil. In: INTERNATIONAL ISHS SYMPOSIUM ON EDIBLE ALLIACEAE, 4. Abstracts... Beijing: ISEA.

BERNO. 2013. Processamento mínimo de cebola roxa: aspectos bioquímicos, fisiológicos e microbiológicos. Piracicaba: USP-ESALQ. 82p. (M.Sc. thesis).

BREWSTER, JL. 1994. Onions and other vegetable alliums. Wallingford: CAB International, 236.

CARDOSO, DSCP; PEREIRA, AM; CORREIA, TD; FINGER, FL. 2016. Drying time and post-harvest quality of onion bulbs submitted to artificial curing. Ceres 63: 822-828.

CARVALHO, VD. 1980. Características nutricionais, industriais e terapêuticas da cebola. Informe Agropecuário 6:71-78.

CRUZ, CD. 2013. Programa Genes - Análise multivariada e simulação. Viçosa: UFV. 1175p.

FERREIRA APS; DE SOUZA CS; PEREIRA AM; CARDOSO DSCP; FINGER FL;RÊGO, ER. 2015. Storage of Onions in Farm Scale Ventilated Silos. Acta Horticulturae1099: 123-128.

GARCIA, JLM; BLEINROTH, EW; YOKOMIZO, Y. 1977. Comportamento das variedades de cebola de maior comercialização no Brasil quanto ao armazenamento. Coletânea do Instituto de Tecnologia de Alimentos 8: 27-53.

JAMIESON, MFS. 1980. Secado e almacenamiento de cebolas. Montevideo: Oficina Regional de la FAO para América Latin. 21p. 
MATOS, AT. 1987. Cura e armazenamento de cebola com utilização de ventilação forçada - Armazém modelo EMPASC, Florianópolis, EMPASC (EMPASC Comunicado Técnico, 113), 12p.

MIGUEL, ACA; DURIGAN, JF. 2007. Quality of onion bulbs cv. Superex stored under refrigeration, when exposed to environmental conditions. HorticulturaBrasileira 25: 301 305.

MINOLTA CORP. 1994. Precise color communication: color control from feeling to instrumentation. $b$ Ramsey: Minolta Corporation Instrument Systems Division. $49 \mathrm{p}$.

MORETTI, CS 2004. Sistema de Produção de Cebola (Allium cepa L) - Colheita e manuseio pós-colheita. Available http://www.cnph. embrapa.br/sistprod/cebola/colheita_e_pos. htm. Accessed April 25, 2013.

MOURA GUERRA, AMN; FERREIRA, JBA; TAVARES, PRF; VIEIRA, TS; MEDEIROS,
AC. 2014. Avaliação das principais causas de perdas pós-colheita de hortaliças comercializadas em Santarém, Pará. Revista Verde de Agroecologia e Desenvolvimento Sustentável 12: 34-40.

PETROPOULOS, SA; NTATSI, G; FERREIRA, ICFR. 2017. Long-term storage of onion and the factors that affect its quality: A critical review. Food Reviews International 33: 62-83.

PROCTOR, FJ; GOODLIFE, JP; COURSEY, DG. 1981. Postharvest losses of vegetables and their control in the tropics. Vegetable Productivity 140-172.

RESENDE, GM; COSTA, ND. 2008. Época de plantio e doses de nitrogênio e potássio na produtividade e armazenamento da cebola. Pesquisa Agropecuária Brasileira 43: 221226.

SEKARA, A; POKLUDA, R; DEL VACCHIO, L; SOMMA, S; CARUSO, G. 2017. Interactions among genotype, environment and agronomic practices on production and quality of storage onion (Allium cepa L.), A review. Horticultural Science 441: 21-42.

SOARES, VLF; FINGER, FL; MOSQUIM, PR. 2004. Influência do genótipo e do estádio de maturação na colheita sobre a matéria fresca, qualidade e cura dos bulbos de cebola. Horticultura Brasileira 22: 18-22.

VIDIGAL, SM; MOREIRA, MA; MAPELI, AM; FINGER, EL. 2010. Efeito da cura na perda pós-colheita de cebola armazenada em condição ambiental não controlada. Revista Brasileira de Armazenamento 35: 125-130.

VOLKIND, IL; ROSLOV, NN; MUKHANOV, PA. 1993. Modern potato and vegetable storage. American Publication Company Ltda. 188p.

ZAIDHAFT, JF. 1984. Produção de cebola no Brasil, Agroanalysis. 13p.

YOKOMIZO, Y; DRAETTA, IS; COSTA, RB; GARCIA, JL. 1977. Composição química de diferentes variedades de cebola (Allium cepa L.) e sua caracterização. Coletânea do Instituto de Tecnologia de Alimentos, 8: 501-517. 